\title{
The Aspects Of Child Development On Early Childhood Education Curriculum
}

\author{
Konstantinus Dua Dhiu \\ Program Studi PG-PAUD, STKIP Citra Bakti, Bajawa, Indonesia \\ e-mail: duakonstantinus082@gmail.com \\ Dek Ngurah Laba Laksana \\ Program Studi PGSD, STKIP Citra Bakti, Bajawa, Indonesia \\ e-mail: laba.laksana.citrabakti.ac.id
}

\author{
A R T I C L E I N F O \\ Article history: \\ 25 December 2020 \\ Received in revised form \\ 01 January 2021 \\ Accepted 25 January 2021 \\ Available online 03 Pebruari \\ 2021 \\ Kata Kunci: \\ Perkembangan Anak Usia \\ Dini, Kurikulum \\ Keywords: \\ Early Childhood \\ Development, Curriculum
}

\begin{abstract}
A B S T R A K
Pemilihan tujuan pembelajaran yang kurang tepat dapat mempengaruhi keberhasilan pelaksanaan pembelajaran, sehingga diperlukan sebuah perangkat pembelajaran dengan memperhatikan perumusan tujuan pembelajaran. Penelitian ini bertujuan untuk menganalisis perangkat pembelajaran mengenai tujuan pembelajaran aspek bahasa, aspek sosial emosional, aspek seni, aspek nilai agama dan moral, dan aspek fisik motorik pada kurikulum tahun 2013. Jenis penelitian ini merupakan penelitian pengembangan dengan model pengembangan Rowntree. Subjek penelitian ini adalah perangkat pembelajaran mengenai tujuan pembelajaran aspek bahasa, aspek sosial emosional, aspek seni, aspek nilai agama dan moral, dan aspek fisik motorik. Metode pengumpulan data yang digunakan dalam penelitian ini adalah dengan menggunakan metode wawancara, metode angket dan metode dokumentasi. Teknik analisis data yang digunakan pada penelitian ini adalah teknik analisis deskriptif kualitatif dan analisis statistik deskriptif kuantitatif. Hasil penelitian ini memperoleh penilaian terhadap perangkat pembelajaran yang dikembangkan dengan nilai rata-rata 4,7 oleh ahli konten, nilai rata-rata 4,3 oleh ahli desain pembelajaran, dan nilai rata-rata 4,6 oleh ahli bahasa. Simpulan penelitian ini adalah. perangkat pembelajaran mengenai tujuan pembelajaran
\end{abstract} aspek bahasa, aspek sosial emosional, aspek seni, aspek nilai agama dan moral, dan aspek fisik motorik pada Kurikulum Kurikulum 2013 dinyatakan layak untuk digunakan dalam pembelajaran anak usia dini (PAUD).

\begin{abstract}
A B S T R A C T
Selection of learning objectives that are not quite right can affect the success of the implementation of learning, so a learning device is needed with attention to the formulation of learning objectives. This study aims to analyze learning tools regarding the learning objectives of language aspects, social emotional aspects, artistic aspects, religious and moral aspects, and physical motor aspects in the 2013 Curriculum curriculum. This type of research is a development research with the Rowntree development model. The subjects of this research are learning tools regarding the learning objectives of language aspects, social emotional aspects, artistic aspects, religious and moral aspects, and motoric physical aspects. The data collection method used in this research is to use the interview method, the questionnaire method and the documentation method. The data analysis technique used in this research is qualitative descriptive analysis technique and quantitative descriptive statistical analysis. The results of this study obtained an assessment of the learning tools developed with an average score of 4.7 by content experts, an average score of 4.3 by learning design experts, and an average score of 4.6 by linguists. The conclusion of this research is. Learning tools regarding the learning objectives of language aspects, social emotional aspects, artistic aspects, religious and moral aspects, and physical motor aspects in the 2013 Curriculum are deemed appropriate for use in early childhood learning.
\end{abstract}

\section{Introduction}

Several factors determine the quality of future life of the nation's children, one of which is education. Educational factors are essential in creating the lives of the nation's children who are intelligent, peaceful, open, independent and democratic (Kristiantari, 2015; Kurniasari, 2017; Mulyadin, 2016). Education must continually be updated to improve the quality of national education and education for anyone, anytime and anywhere, and the level of educational institutions is not limited; even education lasts from birth to the end of life (Ardianingsih et al., 2017; Subadi et al., 2013; Wahyudin, 2018). One level of education in educational institutions is early childhood education.

Early childhood education is a coaching effort aimed at children from birth to age six years conducted by providing educational stimuli to help the growth and development of physical and spiritual so that the child can enter the different education level. According to the National Association of Education for Young Child, early childhood education covers the child's age from birth to eight years (Hartanto et al., 2011; Nahdi \& Yunitasari, 2020; Wati, 2018). 
Early childhood education is held before elementary school through formal, informal and nonformal education channels (Pebriana, 2018; Wasinah; 2015 Wati, 2018). Early childhood education in legal education in kindergarten (PAUD), Rhatul Athfal (RA) or other similar forms. Early childhood education in the form of nonformal education in the form of playgroups (Kober), childcare (TPA), integrated service posts (Posyandu) and other similar forms. Early childhood in the form of informal education in the form of education in the family and community. Early childhood education is an individual figure who is undergoing rapid and fundamental development because early childhood education is experiencing a golden age.

Early childhood development in various aspects, namely the moral aspects of religion, social-emotional, cognitive, motor, physical, language, art and development in the golden period in the stages of life, can determine the subsequent development (Astuti et al., 2020; Fakhriyani, 2016; Mayasari \& Ardhana, 2018). One of them is the development of moral values of religion, social, emotional, language, motor physics and art, where aspects of development include language skills, symbolic thinking, being able to move limbs, praying following the religion, diligently helping and working together, exploring and expressing themselves, imagining with movements, music, drama, and various other areas of development (painting development, visual development, craft), and being able to appreciate developmental works (Laily et al., 2019; Sukmady, 2017; Suryaningsih et al., 2016).

The core activities in every educational institution, especially early childhood education institutions, are the learning process; the learning process includes teacher activities and student activities (Directorate of Kindergarten and Elementary School Development, 2010). The activity of drawing up a learning plan is one of the essential tasks of teachers in processing students' learning. In creating a good quality of education, and maximum results, there needs to be good planning in learning materials, learning media and other teaching planning documents. The implementation of the learning will be successful if a teacher has the ability. One of the skills that every teacher must have is the ability to formulate learning objectives. This skill is an essential part of a teacher's academic competence, planning a teaching and learning program. A teacher's ability to develop learning objectives is a teacher's ability/mastery that includes the potential, knowledge, and skills possessed by teachers in the formulation of behaviours or abilities that students want to achieve at the time of the learning process. The capabilities we expect must be explicitly formulated and operationally to be measured later (Ardianingsih et al., 2017; Purwanti et al., 2014; Wardana, 2018).

In the Preparation of the Daily Learning, Implementation Plan mentioned that one of the components in the preparation of the Daily Learning Implementation Plan is the existence of learning objectives formulated based on essential competencies, using active verbs that can be observed and measured, which include attitudes, knowledge, and skills. One of the crucial things in designing or designing learning is to formulate learning objectives (Karom et al., 2014; Umi et al., 2019; Wardana, 2018).

Based on the observation of learning devices in Early Childhood Education institutions, especially in Ngada Regency, East Nusa Tenggara found the fact that many teachers of group A and B are still mistaken in formulating learning objectives for aspects of moral values of religion, social-emotional, language, cognitive, motor physical and art. Also, there is any inconsistency between the learning media used and the formulation of core competencies, essential competencies, and material content. It is due to teachers who average high school graduation in formulating learning objectives and the lack of resources that can be used as a reference in developing learning objectives. The results showed that knowledge factors are related to the level of child development, so that people need to be informed about child development factors at various age levels (Fakhriyani, 2016; Hartiningsih, 2015; Trimantara \& Mulya, 2019).

In addition to the observations made, researchers have also conducted interviews with early childhood education teachers' group A and B to formulate the purpose of learning aspects of teacher development already use active verbs. Still, teachers in developing learning objectives on the development of moral values of religion, social, emotional, language, cognitive, motor physical and art use sentences such as children can imitate movement well. It shows the preparation of learning objectives development aspects, not yet following the appropriate learning methods and models to formulate learning objectives for early childhood. Learning objectives are one of the learning indicators that must be considered and prepared well adapted to the learning materials (Ardianingsih et al., 2017; Purwanti et al., 2014; Wardana, 2018).

Lack of preciseness in the formulation of learning objectives can impact errors in determining assessment and learning success (Karom et al., 2014; Umi et al., 2019; Wardana, 2018). The formulation of the right learning objectives makes it easier to recognize the development of children in various aspects of development. The study results showed if the strategies or methods used appropriately in developing parts of child development, then the learning outcomes will be optimal (Khofiatun et al., 2016; Mawardi, 2019; Sakti et al., 2019).

In addition to the formulation of appropriate learning objectives, learning environment, teacher competence, and parental participation, and of course, the existence of learning centres need to get attention (Purwanti et al., 2014; Umi et al., 2019; Wardana, 2018). These factors are certainly a consideration in 
developing learning objectives. By paying attention to these factors, it is expected that learning properly measures the achievement of learning outcomes in various aspects of children's development.

Based on the above problems, the solution that can be used in developing learning is to use the learning model of Morrison, Ross and Kemp. The MRK learning model is used as a foothold in early childhood development aspects in the 2013 early childhood education curriculum of groups A and B. One of the reasons researchers use the Morison, Ross and Kemp learning model is that Morrison, Ross and Kemp contain nine steps of learning objective development in the learning model.

This research is supported by several relevant previous studies, namely the first research conducted by (Dewi et al., 2020), which obtained the research results of rapid development in school age, namely the development of language, emotions, and social children. Both studies conducted by (Surya, 2017) which obtained the study results that the use of learning models can facilitate the education of 21 st-century characters in early childhood. The three studies conducted by (Hidayah et al., 2016) obtained the results of the study that there is a relationship of maternal parenting patterns with the level of language development in early childhood.

This study aims to analyze learning tools on the learning objectives of language aspects, social and emotional aspects, aspects of art, religious and moral values, and physical-motoric aspects in the 2013 curriculum.

\section{Method}

In this study, the development of the model used is the development model in learning devices and teaching materials, namely the Rowntree model (Widyastuti, 2018). The reason researchers used this research model because the research and development could solve problems that occur in the educational environment, such as being able to produce products that could be used in the world of education, such as learning models and good learning tools in the future. Rowntree's development model consists of three stages: the planning stage, the development stage, and the evaluation stage.

The subject of this study was a learning tool on the purpose of learning aspects of language, social aspects of emotion, aspects of art, aspects of religious and moral values, and physical aspects of motor. Assessments of refined products were assessed by content experts, learning design experts, and linguists.

The method of data collection used in this study is to use interview methods, questionnaire methods and documentation methods. The instruments used in this study are questionnaires of learning device assessments given to content experts, learning design, and language.

This development research used two data analysis techniques: qualitative descriptive analysis techniques and quantitative descriptive statistical analysis. Qualitative Descriptive Analysis Techniques utilized to revise the product being developed. This revision is from input, advice from some content or content experts, learning design experts and linguists. Descriptive Statistical Analysis Techniques Quantifiable used to process data derived from questionnaires in the form of descriptive percentages. In determining the conclusions reached, the criteria were set according to the table of validity levels.

\section{Result and Discussion}

From the results of the interview, researchers obtained information that in the use of the content of learning materials with the purpose of learning is still found errors, especially in compiling the content of lesson materials in early childhood Groups A and B for aspects of the development of Moral Values of Religion, Social-Emotional, Language, Cognitive, Physical Motor and Art. The first step in making learning is to formulate the learning objectives. The researchers can find out the learning objectives of what studies will be displayed in the development of learning objectives aspects of the development of Moral Values of Religion, Social-Emotional, Language, Cognitive, Physical motoric and Art based on Morrison, Ross and Kemp models in the 2013 curriculum of early childhood education and ultimately determine how much learning goals are achieved. At this stage, the researchers analyzed learning devices through observation to determine the school's conditions. The researcher performed research on the characteristics of early childhood in early childhood education, which located in Golewa Subdistrict, especially groups A and B. Researchers conducted interview activities on ten teachers for ten different kindergartens in Golewa Subdistrict, Ngada Regency

Based on the analysis results at the previous stage of planning, they were used to develop the learning objectives of the development of Moral Values of Religion, Social-Emotional, Language, Motor Physical and Art in early childhood Group A and B. This development stage was carried out by compiling learning tools. At this stage of development, researchers discussed the results of the development of learning objectives aspects of the development of Moral Values of Religion, Social-Emotional, Language, Cognitive, Motor Physical and Art based on the Morrison Ross and Kemp model on the curriculum 2013 Early Childhood Education Group A and B. The development of learning objectives aspects of the development of Moral Values of Religion, Social- 
Emotional, Language, Cognitive, Physical Motor and Art based on the model Morrison Ross and Kemp were as follows. The learning tools developed were the annual program, a semester program, Weekly Learning Implementation Plan, and Daily Learning Implementation Plan.

Aspects of Religious and Moral Values in early childhood learning include Knowing the religion embraced, doing worship, behaving honestly, helping, polite, respectful, sportsmanship, maintaining personal and environmental hygiene, maintaining personal and environmental hygiene, knowing the great day of religion and respecting of other people's religions. Each of these aspects had been developed into a learning objective. Learning Objectives on NAM aspects created using Ross, Morisson, and Kemp models in early childhood learning ages 4-5 years and 5-6Years.

Aspects of Art in early childhood learning include Exploring and expressing themselves, imagining with movement, music, drama, and various other art fields, be able to appreciate artworks. Each of these aspects had been developed into a learning objective. Learning Objectives on aspects of art created using the Ross, Morisson, and Kemp models.

Aspects of Language in early childhood learning include the understanding language: performance stories, commands, rules, and enjoying and appreciating reading, expressing language: being able to ask, answer questions, communicate verbally, retell what children experience, Literacy: understanding the relationship of form and sound of letters, imitating letter form, and understanding the word in the story. Each of these aspects had been developed into a learning objective. Learning objectives on the art aspect created using the ross, morisson, and kemp models in early childhood learning ages 4-5 years and 5-6 years.

Social aspects of emotional learning in early childhood education include self-ability, knowing selffeeling and self-control, and being able to adjust to others, prosocial behaviour: being able to play with peers, understanding feelings, responding, sharing, and respecting the rights and opinions of others; be cooperative, tolerant, and behave politely, a sense of responsibility for yourself and others.

Physical-motoric aspects of early childhood learning include rough motor, among others, having the ability to move in a coordinated flexible, balanced, agile and others and fine motor can use tools to explore and express themselves in various forms. Each of these aspects had been developed into a learning objective. Learning objectives in the art aspect created using the Ross, Morisson, and Kemp models in early childhood learning ages 4-5 years and 5-6 years.

This trial was conducted to obtain the results of the products that had been made and to obtain input if there were still errors related to the content contained in the product development of learning objectives aspects of the development of Moral Values of Religion, Social-Emotional, Language, Physical-motoric and Art. The results of this trial were conducted through assessment through questionnaire sheets. The product trials and revisions from content experts that add rubric assessment. Before the revision, the value obtained after the revision accumulated for each aspect was excellent. This program was declared very valid by the content expert.

Assessment of learning device products involved ten teachers, namely early childhood teachers from TKN Nazareth Were, Integrated PAUD Citra Bakti, Kober Setara Tk Peupado, TKKN Harapan Bangsa Koeloda, TKK Ade Irma Mataloko, TKK Skolastika Waeia, Kober Setara TK Ratogesa, TKK Satap Rutosoro, TKK Sinar Mentari Doka, TKK Negeri Dolupore in Ngada Regency, NTT. Product assessment of learning objectives of various aspects of early childhood development by content experts, learning design experts, and linguists can be seen in Table 1.

Table 1. Product assessment of learning objectives of various aspects of early childhood development by content experts, learning design experts, and linguists

\begin{tabular}{ccc}
\hline Scoring & Mean & Category \\
\hline Content Expert & 4,7 & Very Good \\
Learning Design Expert & 4,3 & Very Good \\
Linguist Expert & 4.6 & Very Good \\
\hline
\end{tabular}

Product test results developed by content experts indicate the products developed there in the category were excellent. Product trial results by learning design experts provide an assessment of the products developed in the category. The results of product trials by linguists assess the products produced in the category very well. Of the three test results, the learning objectives developed were eligible for use in early childhood learning.

The development of learning objectives conducted by researchers on the aspects of the development of religious, moral values, social-emotional, language, physical-motoric and art based on the Morrison Ross and Kemp models consists of four main parts, namely: (1) Annual Program, (2) Semester Program, (3) Weekly Learning Implementation Plan, (4) Daily Learning Implementation Plan. Here was a description of each section to learn aspects of the development of religious, moral values, social-emotional, language, motor physics, and art based on the model Morrison Ross and Kemp have developed. 
The annual program was a learning plan prepared for learning in one school year consisting of semester I and semester II. The yearly program planning consists of themes, sub-themes, sub-sub themes, and time allocation developed by aspects of religious, moral values, social-emotional, language, motor physics, and early childhood art. The semester program was a learning planning that will be conducted for one semester. It was a description of the annual program, which consists of aspects of the development of Moral Values of Religion, Social-Emotional, Language, Physical-motoric and Arts, standard level of achievement of early childhood development, core competencies (KI), basic competencies (KD), material content, learning objectives in the purpose of learning using operational verbs and using the formula A, B, C, D, in accordance with the aspects of development and characteristics of early childhood.

Weekly Learning Implementation Plan was a description of the semester program that contains learning activities for one week following the theme and sub-themes studied. In developing the Weekly Learning Implementation Plan, the author used cobwebs and central learning models such as preparatory centers, block centers, role-playing centres, and development centres. RPPH is a description of the implementation of weekly learning used in daily learning. The development of the Daily Learning Implementation Plan consists of semesters, weeks, days, themes, sub-themes, groups, ages, school years, core competencies, basic competencies, learning materials, learning objectives, learning methods, learning steps, tools and materials, assessment plans, and reading resources. The purpose of learning aspects of the development of moral values of religion, socialemotional, language, motor physics and art using the model Morrison, Ross and Kemp developed in this study had been revised based on experts' comments.

The development of the annual program, semester program, Weekly Learning Implementation Plan, and Daily Learning Implementation Plan were in line with the model and planning in early childhood learning. The development of these components as a result of the learning objectives that had been developed. The development of learning objectives was based on active verbs to make it easier to conduct assessments. This was in line with the development undertaken by (Astuti et al., 2020; Fakhriyani, 2016; Mayasari \& Ardhana, 2018) that the results of the development of learning objectives in the cognitive aspects of early childhood were worth using in learning.

The formulation of the right learning objectives makes it easier to recognize the development of children in various aspects of development. The results of the study showed if the strategies or methods used appropriately in developing parts of child development, then the learning outcomes achieved will be optimal (Laily et al., 2019; Sukmady, 2017; Suryaningsih et al., 2016).

This research was supported by several relevant previous studies, namely the first research conducted by (Dewi et al., 2020), which obtained the research results that aspects of rapid development in school age, namely the development of language, emotions, and social children. Both studies conducted by (Surya, 2017), which obtained the study results that the use of learning models can facilitate the education of 21 st-century characters in early childhood. The three studies conducted by (Hidayah et al., 2016), which obtained the results of the study that there was a relationship of maternal parenting patterns with the level of language development in early childhood.

\section{Conclusion}

Based on the results of the analysis and discussion, it can be concluded that the learning tools that have been developed regarding the purpose of learning aspects of language, social and emotional aspects, aspects of art, aspects of religious and moral values, and aspects in the curriculum in 2013 are declared eligible for use in early childhood learning.

\section{References}

Ardianingsih, F., Mahmudah, S., \& Rianto, E. (2017). Peran Guru Dalam Implementasi Kurikulum 2013 Pendidikan Khusus Pada Sekolah Luar Biasa Di Sidoarjo. Jurnal Pendidikan, 2(1), 14-20. https://doi.org/10.26740/jp.v2n1.p21-30

Astuti, H. P., Nugroho, A. A. E., \& Dewi, N. A. R. (2020). Penerapan Model Pembelajaran Picture and Picture Berbasis Keanekaragaman Hayati Dalam Pembentukan Empati Anak Usia Dini. Intuisi: Jurnal Psikologi Ilmiah, 12(1), 66-74. https://doi.org/10.15294/intuisi.v12i1.23573

Dewi, M. P., S, N., \& Irdamurni, I. (2020). Perkembangan Bahasa, Emosi, Dan Sosial Anak Usia Sekolah Dasar. Jurnal Ilmiah Pendidikan Dasar, 7(1), 1-11. https://doi.org/10.30659/pendas.7.1.1-11

Fakhriyani, D. V. (2016). Pengembangan Kreativitas Anak Usia Dini. Wacana Didaktika, 4(2). https://doi.org/10.31102/wacanadidaktika.4.2.193-200 
Hartanto, F., Selina, H., H, Z., \& Fitra, S. (2011). Pengaruh Perkembangan Bahasa Terhadap Perkembangan Kognitif Anak Usia 1-3 Tahun. Sari Pediatri, 12(6), 386-390. https://doi.org/10.14238/sp12.6.2011.386-90

Hartiningsih, S. (2015). Revitalisasi Lagu Dolanan Anak dalam Pembentukan Karakter Anak Usia Dini. Atavisme, 18(2), 247-259. https://doi.org/10.24257/atavisme.v18i2.119.247-259

Hidayah, N., Prabowo, T., \& Najmuna, A. (2016). Pola Asuh Ibu Berhubungan dengan Tingkat Perkembangan Bahasa pada Anak Prasekolah di TK Al Farabi Yogyakarta. Jurnal Ners Dan Kebidanan Indonesia, 1(2), 48-54. https://doi.org/10.21927/jnki.2013.1(2).48-54

Karom, D., Ruhimat, T., \& Darmawan, D. (2014). Pengaruh Kompetensi Pedagogik Guru Dalam Menerapkan Pembelajaran Kooperatif Berbantuan Media Presentasi Terhadap Hasil Belajar Peserta Didik Pada Mata Pelajaran Matematika. Edutech, 13(2), 274-308. https://doi.org/10.17509/edutech.v13i2.3113

Khofiatun, Akbar, S., \& Ramli, M. (2016). Peran Kompetensi Pedagogik Guru Dalam Pembelajaran Tematik Di Sekolah Dasar. Jurnal Pendidikan, 1(5), 984-988. https://doi.org/10.17977/jp.v1i5.6336

Kristiantari, R. (2015). Analisis Kesiapan Guru Sekolah Dasar dalam Mengimplementasikan Pembelajaran Tematik Integratif Menyongsong Kurikulum 2013. JPI (Jurnal Pendidikan Indonesia), 3(2), 460-470. https://doi.org/10.23887/jpi-undiksha.v3i2.4462

Kurniasari, F. (2017). Implementasi Pendekatan Saintifik Pada Penugasan Aktivitas Di Buku Teks Bahasa Indonesia Kelas VII SMP Berdasarkan Kurikulum 2013. Jurnal Pendidikan Edutama, 4(1), 9-26. https://doi.org/10.30734/jpe.v4i1.44

Laily, A., Jalal, F., \& Karnadi, K. (2019). Peningkatan Kemampuan Konsep Matematika Awal Anak Usia 4-5 Tahun melalui Media Papan Semat. Jurnal Obsesi : Jurnal Pendidikan Anak Usia Dini, 3(2), 396-403. https://doi.org/10.31004/obsesi.v3i2.214

Mawardi. (2019). Optimalisasi Kompetensi Guru Dalam Penyusunan Rencana Pelaksanaan Pembelajaran. Jurnal Ilmiah Didaktika: Media Ilmiah Pendidikan Dan Pengajaran, 20(1), 69 - 82. https://doi.org/https://doi.org/10.22373/jid.v20i1.3859

Mayasari, D., \& Ardhana, N. R. (2018). Publikasi Bentuk Fungsi dan Kategori SintaksisTuturan Masyarakat Manduro sebagai Pendukung Perkembangan Bahasa Anak Usia Dini. Jurnal Obsesi : Jurnal Pendidikan Anak Usia Dini, 2(1), 54-63. https://doi.org/10.31004/obsesi.v2i1.7

Mulyadin. (2016). Implementasi Kebijakan Pembelajaran Tematik Terpadu Kurikulum 2013 Di SDN Kauman 1 Malang Dan SD Muhammadiyah 1 Malang. Jurnal Edutama, 3(2), 31-48. https://doi.org/10.30734/jpe.v3i2.35

Nahdi, K., \& Yunitasari, D. (2020). Literasi Berbahasa Indonesia Usia Prasekolah: Ancangan Metode Dia Tampan dalam Membaca Permulaan. Jurnal Obsesi : Jurnal Pendidikan Anak Usia Dini, 4(1), 434441. https://doi.org/10.31004/obsesi.v4i1.372

Pebriana, P. H. (2018). Analisis Penggunaan Gadget terhadap Kemampuan Interaksi Sosial pada Anak Usia Dini. JURNAL OBSESI, 1(1), 1-11. https://doi.org/10.31004/obsesi.v1i1.26

Purwanti, K., AR, M., \& Yusrizal, Y. (2014). Kepemimpinan Kepala Sekolah Dalam Meningkatkan Kompetensi Guru Pada Smp Negeri 2 Simeulue Timur. Jurnal Ilmiah Didaktika, 14(2), 390-400. https://doi.org/10.22373/jid.v14i2.510

Sakti, T. K., Hairunisya, N., \& Sujai, I. S. (2019). Pengaruh Kompetensi Pedagogik Guru dan Gaya Belajar Siswa Terhadap Prestasi Belajar Siswa Pada Mata Pelajaran IPS. Jurnal Pendidikan Ilmu Sosial, 28(1), 53-60. https://doi.org/10.17509/jpis.v28i1.12818

Subadi, T., Priyono, K. D., Dahroni, \& Musyiyam, M. (2013). Implementasi Pembelajaran IPS Berbasis Kurikulum 2013 Melalui Lesson Study Di Sekolah Muhammadiyah Kartasura. WARTA, 18(1), 62-76. https://doi.org/10.23917/warta.v18i1.1168

Sukmady, F. W. (2017). Meningkatkan Kemampuan Berempati Anak Usia 5-6 Tahun Melalui Cooperative Learning. Jurnal Penelitian Dan Pengembangan Pendidikan Anak Usia Dini, 4(2). https://doi.org/10.30870/jpppaud.v4i2.4650

Surya, Y. F. (2017). Penggunaan Model Pembelajaran Pendidikan Karakter Abad 21 pada Anak Usia Dini. Jurnal Obsesi : Jurnal Pendidikan Anak Usia Dini, 1(1), 52-61. https://doi.org/10.31004/obsesi.v1i1.30 
Suryaningsih, N. M. A., Cahaya, I. M. E., \& Poerwati, C. E. (2016). Implementasi Pembelajaran Inkuiri Terbimbing Berbasis Permainan Dalam Meningkatkan Kreativitas Anak Usia Dini. JPI (Jurnal Pendidikan Indonesia, 5(2), 512-220. https://doi.org/10.23887/jpi-undiksha.v5i2.8559

Trimantara, H., \& Mulya, N. (2019). Mengembangkan Bahasa Anak Usia 4-5 Tahun Melalui Alat Permainan Edukatif Puzzle. Al-Athfaal: Jurnal Ilmiah Pendidikan Anak Usia Dini, 2(1), 25-34. https://doi.org/10.24042/ajipaud.v2i1.4553

Umi, R., Nopriansyah, U., \& Purnama, S. (2019). Korelasi Kepemimpinan Kepala Taman Kanak-Kanak Terhadap Kinerja Kompetensi Pedagogik dan Kompetensi Profesional Guru. Al-Athfaal: Jurnal Ilmiah Pendidikan Anak Usia Dini, 2(1). https://doi.org/10.24042/ajipaud.v2i1.4552

Wahyudin, W. (2018). Optimalisasi Peran Kepala Sekolah dalam Implementasi Kurikulum 2013. Jurnal Kependidikan, 6(2), 249-265. https://doi.org/10.24090/jk.v6i2.1932

Wardana. (2018). Peningkatkan Kompetensi Guru Sekolah Dasar Dalam Mengimplementasikan Standar Proses Pembelajaran Melalui Supervisi Kolegial Teknik Kunjungan Antar Kelas. Jurnal Tarbawi, 15(1), 93112. https://doi.org/10.34001/tarbawi.v15i1.721

Wasinah, W. (2015). Peran Pola Asuh Otoritatif Orang Tua, Pendidikan Orang Tua dan Jumlah Saudara Terhadap Kemandirian Anak. PSIKOPEDAGOGIA Jurnal Bimbingan Dan Konseling, 4(2), 104-114. https://doi.org/10.12928/psikopedagogia.v4i2.4481

Wati, N. S. (2018). Pengaruh Stimulasi Mendengarkan Lagu Dan Bernyayi Terhadap Perkembangan Berbahasa Pada Anak Usia Dini. Elementary: Jurnal Ilmiah Pendidikan Dasar, 4(1), $75-84$. https://doi.org/10.32332/elementary.v4i1.1081 